\title{
A brief history of scrotal cancer
}

\author{
H A WALDRON
}

From the TUC Centenary Institute of Occupational Health, London School of Hygiene and Tropical Medicine, London WCIE 7HT, UK

Scrotal cancer has a particular interest for students of the history of occupational medicine as it was the first malignant disease to be connected with a specific occupation when in 1775 Percivall Pott described its occurrence in chimney sweeps. ${ }^{1}$ Although it does arise spontaneously, most cases of scrotal cancer are associated with some occupational hazard. Since the eighteenth century there have been at least three major occupational groups in which the prevalence of the disease has been unusually great, chimney sweeps, those who work with the distillates of coal, and men exposed to mineral oil.

\section{Chimney sweeps}

The classic description of scrotal cancer in chimney sweeps was contained in Pott's Chirurgical Observations. ${ }^{1}$ Pott (fig 1) was the first to attribute an occupational cause to the disease but his was not the first description of the tumour itself. It is customary to give priority for the description of the disease to Bassius in 1731, but Kipling et al have questioned whether the lesion Bassius described really was carcinoma. ${ }^{2}$ They considered that the clinical condition was much more suggestive of perineal abscess formation with sinuses leading to the scrotum and they consider that the first true account of scrotal cancer was given by Treyling in 1740 .

Pott was greatly moved by the plight of the patients he saw with the disease writing that:

"The fate of these people seems singularly hard; in their early infancy they are most frequently treated with great brutality, and almost starved with cold and hunger; they are thrust up narrow, and sometimes hot chimneys, where they are buried, burned and almost suffocated; and when they get to puberty, become liable to a most noisome, painful, and fatal disease."

The appalling conditions to which the chimney boys were subjected were a cause of great social concern in the latter part of the eighteenth century, and in 1803 a society was formed to promote the use

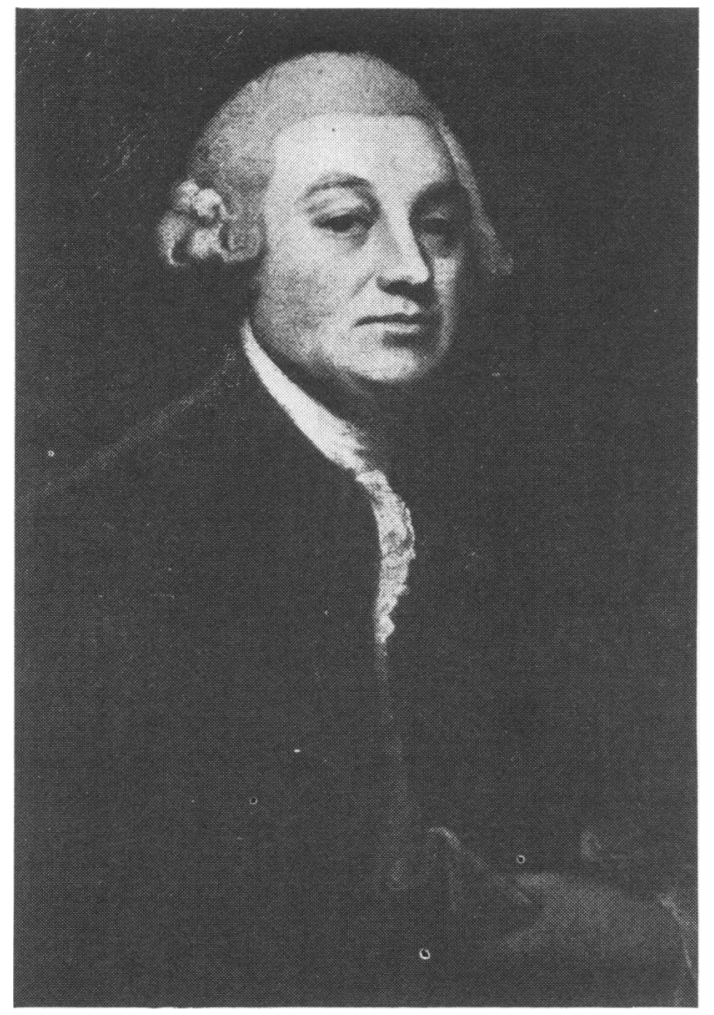

Fig 1 Percivall Pott.

of mechanical means of sweeping chimneys, thus superseding the necessity for climbing boys. Boys had not been used extensively to sweep chimneys until the end of the seventeenth century, when the design of chimneys had been altered during the period of rebuilding after the Great Fire of London. The chimneys were often angular and narrow, the usual dimensions of the flue being no more than $9 \times 14$ inches $(22.8 \times 35.5 \mathrm{~cm})$. The boy sweeps often climbed in the nude, propelling themselves forward by their knees and elbows which were scraped raw in the process. They were frequently 
put up hot chimneys, sometimes even for the purpose of extinguishing chimney fires.

Chimneys with sharp angles presented a particular hazard to the climbing boys. In one of the several anonymous tracts circulated in the campaign to limit the trade, one sweep described the common outcome of putting a boy up such a chimney. ${ }^{3}$

\begin{abstract}
"After passing through the Chimney and descending to the second angle in the fire-place, the Boy finds it completely filled with soot, which he has dislodged from the sides of the upright part. He endevours to get through, and succeeds in doing so, after much struggling as far as his shoulders; but finding that the soot is compressed hard all around him, by his exertions, that he can recede no farther; he then endevours to move forward, but his attempts in this respect are quite abortive; for the covering of the horizontal part of the Flue being stone, the sharp angle of which bears hard on his shoulders, and the back part of his head ... prevents him from moving in the least either one way or the other. His face, already covered with a climbing cap, and being pressed hard in the soot beneath him, stops his breath. In this dreadful condition he strives violently to extricate himself, but his strength fails him; he cries and groans, and in a few minutes he is suffocated. An alarm is then given, a brick-layer is sent for, an aperture is perforated in the Flue, and the boy is extracted, but found lifeless. In a short time an inquest is held, and a Coroner's Jury returns a verdict of 'Accidental Death.'"
\end{abstract}

In 1817 the House of Commons appointed a committee to report on the employment of boys in sweeping chimneys. The committee recommended that the practice should be prohibited and mechanical means of sweeping chimneys introduced instead. The Bill putting this recommendation into effect passed through the Commons but was thrown out by the Lords after petitions against it by master chimney sweeps and by some of the agents for the fire insurance offices. Great play was made of reports of fires breaking out in chimneys which had recently been swept by mechanical means, as was the contention by the sweeps that there was no way of repairing the contorted flues other than by sending up a boy with trowel and mortar. Consequently, it was not until 1840 that an Act was passed to prohibit the sending of boys up chimneys. This Act came into effect on 1 July 1842 but the custom continued in many parts of the country for at least another 20 years. ${ }^{45}$

Pott's account of the signs, symptoms, progress, and treatment of the disease which resulted from this terrible occupation took no more than 500 words. ${ }^{1}$ It first appeared on:

"the inferior part of the scrotum; where it produces a superficial, painful, ragged, ill-looking sore, with hard and rising edges ... In no great length of time, it pervades the skin, dartos, and membranes of the scrotum, and seizes the testicle, which it enlarges, hardens, and renders truly and thoroughly distempered; and whence it makes its way up the spermatic process into the abdomen, frequently indurating and spoiling the inguinal glands. When arrived within the abdomen, it affects some of the viscera, and then very soon becomes painfully destructive."

Unfortunately Pott never wrote more on the disease nor, to judge from the extant manuscript notes taken at his surgical lectures between 1767 and 1785 , did he discuss it with his students. Thus we do not know how frequently he saw patients with the disease, nor when he saw his first case. His description, however, produced in its wake a succession of accounts by other authors. After the publication of his tract, clinical reports began to appear with some regularity, suggesting that others had observed the condition without fully realising what it was. Pott had already hinted that this was indeed the case. The disease invariably appeared after puberty which was the reason (said Pott) that:

"it is generally taken, both by patient and surgeon, for venereal, and being treated with mercurials, is thereby soon and much exasperated."

The patients with the disease were generally young men. Henry Earle, writing in 1832, considered that most cases presented between the ages of 30 and 40 ; he had seen only three cases between the ages of 20 and 30 and only one case before puberty. ${ }^{6}$ The age of onset does not seem to have changed much during the century. An analysis of 36 cases gathered from the eighteenth and nineteenth century literature by Green shows that the mean age of presentation was 37.7 years. ${ }^{4}$ The youngest reported case was in a boy of less than eight years to whom James Earle (Pott's son in law) refers in an annotation to a new edition of Pott's book in $1790 .{ }^{8}$ Earle showed the boy, who was apprenticed to a sweep, to Pott who confirmed the diagnosis. The disease had affected all the lower part of the scrotum but not the testes. The diseased part of the scrotum was removed, the wound healed, and the boy was discharged perfectly well. Whether this truly was scrotal cancer there is no means of knowing at this remove, but we must assume that Pott would not mistake the diagnosis and this was clearly a most exceptional case.

Several writers remarked on the relatively late age of onset, many years after the individual had ceased climbing chimneys, when he was most exposed to soot. There were even cases in which the disease had appeared many years after the man had given up chimney sweeping altogether and was following 
some other trade. Curling described such a case in a man who had been at sea for 19 years, ${ }^{9}$ and Henry Earle noted the disease appearing after an interval of 15 years in other work. ${ }^{6}$ This time lag was never fully explained and indeed could not have been until the concept of the latent period in tumour induction had been established in the present century.

The disease was usually preceded by the development of hyperkeratotic lesions on the scrotum, which the sweeps called soot warts. These soot warts might also develop on other parts of the body and Paget reported that he had seen sweep's "so thick-set with them that a hundred or more have been counted." 10

It was by no means uncommon for the sweeps to treat these soot warts themselves. When one developed on the scrotum, the patient might "pare it with a knife", ${ }^{11}$ while George Lawson recorded that a man who was admitted to the Middlesex Hospital under his care had a wart on his scrotum, ${ }^{12}$ which:

"he ... seized with a split stick and cut off with a razor. He remarked that it was not very painful. $\mathrm{He}$ resumed work the following day."

In some cases the removal of the wart effected a cure but when malignant change supervened, simple measures were no longer effective. Patients frequently delayed seeking medical help, no doubt wishing to put off surgical intervention for as long as possible; when, finally, they were compelled to attend the surgeon, many were in a deplorable state. Jeffreys described the lesion in a 28 year old sweep who consulted him in $1825 .^{13}$

\begin{abstract}
"The sore occupies the whole of the left side of the scrotum and the inner angle of the thigh, extending from the anus to the posterior inferior spinous process of the ileum, presenting a surface as large as a man's open hand, with hard indurated edges and irregular margins, discharging a thin sanies, which is extremely offensive; the left testicle is entirely denuded, and projects from its centre; in the left groin is a mass of indurated glands, the size of a goose's egg, which appears to suppurate in the right groin: there is likewise an ulceration, of the same malignant nature, about the size of a half-crown ..."
\end{abstract}

Despite the appearance of this growth, the unfortunate man was in no pain and his only complaint was that about 10 days before his admission he had bled from his groin and lost about a pint of blood. Even this, however, had not unduly affected his constitution.

Most writers considered that the only treatment of value was complete excision of the growth and cessation of contact with soot thereafter. Astley Cooper, however, advocated as an alternative, sloughing with an arsenical paste..$^{14} \mathrm{~A}$ dram of oxide of arsenic was mixed with an ounce of ceratum cetacii, spread on a lint, and applied to the ulcerated scrotum where it remained for 12 hours. The lint was replaced with a poultice and the slough separated in a few days leaving a raw surface which gradually re-epithelialised. If the growth was not removed completely, or if it recurred, then the arsenic paste was re-applied. (It is ironic that arsenic was itself later incriminated as causing the same disease for which it was used as a cure. See, for example, Hutchinson..$^{15}$ )

No doubt the patients in the early part of the nineteenth century were glad to accept this treatment rather than submit to surgery, although prompt removal offered the best prospect of a cure. To the surgeon the operation was "a simple piece of dissection" 14 but for the patient, before the introduction of anaesthesia, it was a formidable ordeal. Richard Wright, giving evidence before the Committee on the Employment of Boys in Sweeping Chimneys in $1817,{ }^{16}$ said that "they have such a dread of the operation that they will not submit to it." There is a graphic account of the operation performed by William Sands Cox at the Queen's Hospital in Birmingham written by his house surgeon, Peter Bird, which helps us to understand the sweeps' apprehensions. ${ }^{17}$ The patient was a 46 year old sweep who had already attempted removal with a razor himself. The operation took place on 21 October 1846.

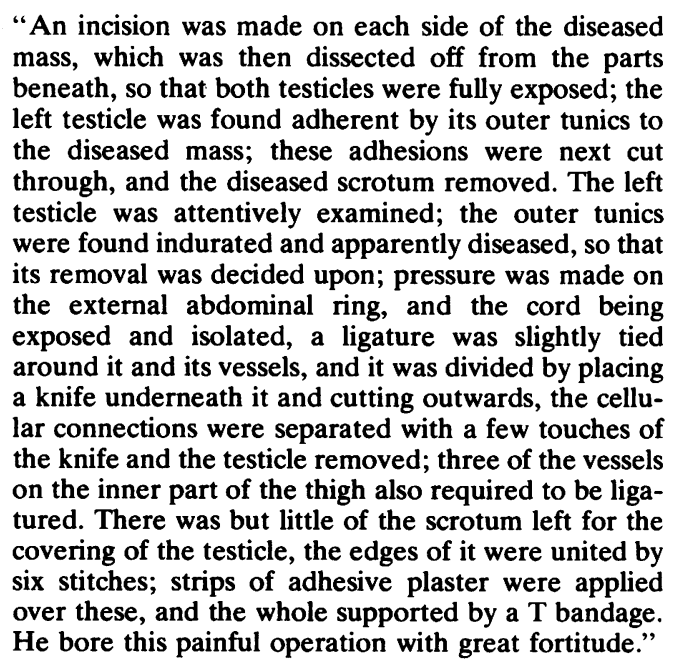

The aetiology of the disease was subject to much speculation from the time of Pott throughout the whole of the nineteenth century. Pott was inclined to blame its origin on the lodgement of soot in the rugae of the scrotum where it gave rise to local irritation and, until the midpoint of the nineteenth cen- 
tury, this view was subscribed to and propagated by such authorities as Astley Cooper, ${ }^{14}$ James and Henry Earle, ${ }^{68}$ Sands Cox, ${ }^{17}$ and Travers. ${ }^{18}$ Later authors, however, thought that other factors were also involved. A major stumbling block in accepting the theory of simple irritation was that even among sweeps, all of whom might be presumed to be more or less equally exposed to soot, the disease was rare. Nor were the sweeps renowned for their cleanliness so that the soot would be in contact with the scrotum for long periods. Why was it then that more of them did not contract the disease? Bransby Cooper postulated that the soot acted to produce the disease only in those in whom there was already a constitutional malignant tendency. ${ }^{19}$ Cooper's hypothesis was found acceptable by other writers, but it did nothing to clarify the position, merely adding a new variable. The question now became, not "How does soot cause cancer?" but, "How does soot cause cancer in those of a cancerous diathesis?" Paget answered this second question as he might have answered the first by saying, "How it does this I cannot imagine." 10

In 1890 Spencer claimed to have discovered soot particles in cells in the deep layers of the epidermis of sweeps who had scrotal cancer and postulated that it was the presence of the irritant within the cells that induced the malignant change. ${ }^{20} \mathrm{His}$ conclusions were almost certainly in error since what he took for soot in his preparations was some artefact of his staining technique. Experimental evidence of the presence of weak carcinogens in soot was finally produced in 1922, however, when Passey succeeded in producing tumours in mice after the application of an ethereal extract of soot. ${ }^{21}$

A feature of the disease which exercised those interesed in it, and which was connected with its aetiology, was that chimney sweeps' cancer seemed to be almost exclusively an English disease. Cases were virtually unknown on the Continent, in America, or even in Scotland. This problem was fully investigated by Henry Butlin (fig 2). Butlin (1845-1912) was a surgeon at St Bartholomew's hospital; an eminent laryngologist, he was president of the Royal College of Surgeons from 1909 to 1911 , and he received a baronetcy on the occasion of the coronation of George V. His investigations into scrotal cancer occupied him from 1889 to 1891 and his observations were reported in a series of three lectures to the Royal College of Surgeons in 1892. ${ }^{22}$ These lectures were the most important contribution to the understanding of the disease since Pott.

Butlin took himself to the Continent during the course of his researches and, as the result of meeting and talking to Continental sweeps, he considered

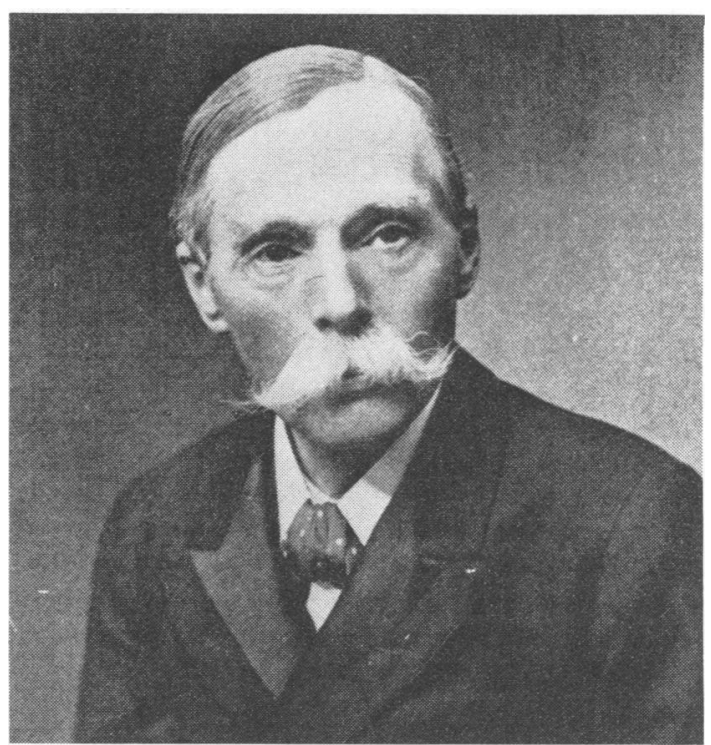

Fig 2 Sir Henry Butlin.

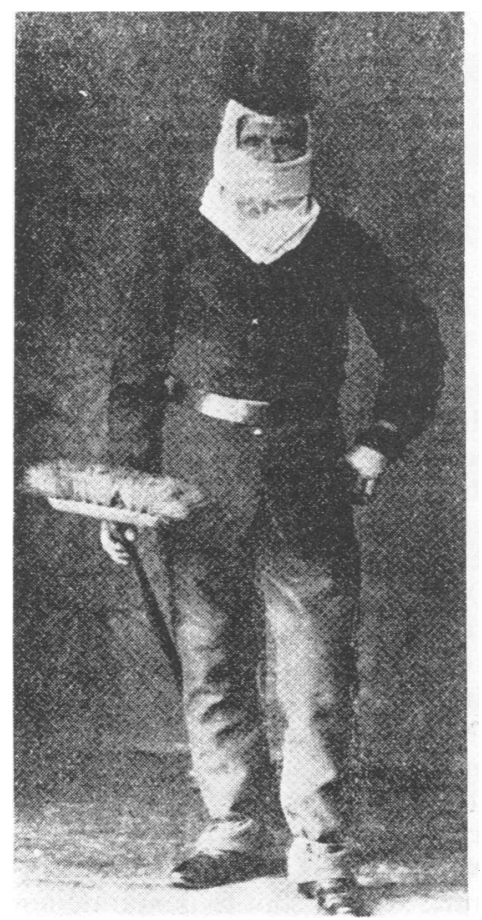

Fig 3 Protective clothing worn by a German sweep in 1890s. Illustration from Butlin ${ }^{22}$; reproduced with the permission of the Wellcome Institute for the History of Medicine. 


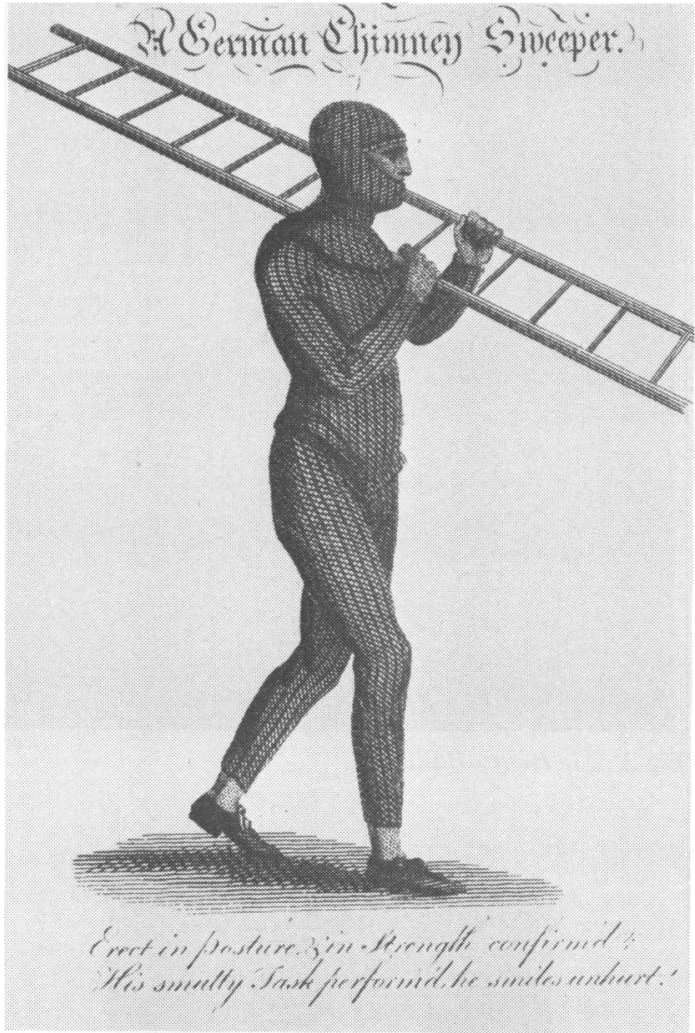

Fig 4 Protective clothing worn by a German sweep in 1785 .

that he had established the reasons for the virtual absence of scrotal cancer among them. In part it was due to the protective clothing they wore (fig 3 ). This consisted of a blouse with long sleeves tied at the wrist; the blouse was tucked inside the trousers which were fastened tightly at the waist with a belt. The sweep also wore gaiters and boots tied at the ankle. Over his head he wore a hood which was tied closely around the neck when he was sweeping. Compared with this, the British sweep wore clothes which fitted loosely (if at all), open necked shirts, and no head covering.

Attention to personal hygiene had a long history among the Continental sweeps. As early as 1785, the German sweep (fig 4) is depicted in a close fitting suit complete with head covering. There are no openings for the soot to penetrate nor any loose clothing in which it can lodge. The London sweep, as late as 1851 (fig 5) stands in sharp contrast, a waiflike boy, dirty and in loose smock and trousers.

During the course of his investigations, Butlin also

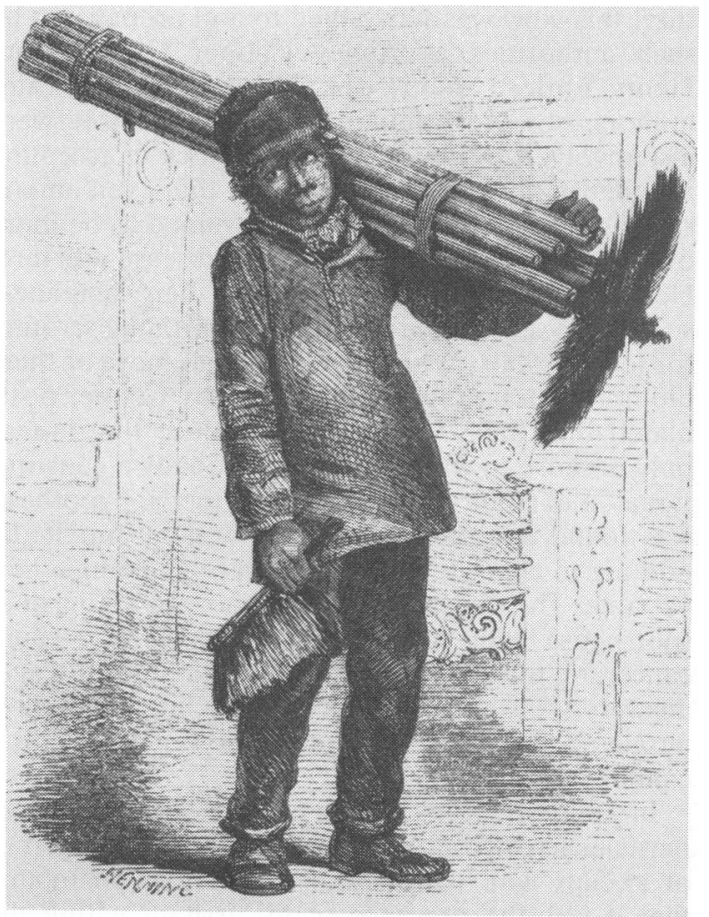

Fig 5 An English chimney sweep in 1851.

applied himself to one further aspect of the disease. As the nineteenth century progressed, an impression was formed in the minds of surgeons that the disease was becoming less common. This was generally attributed to the passing of the Chimney Sweeps' Act in 1840 which prohibited boys going up the chimneys. George Lawson expressed a different point of view, however ${ }^{23}$ His contention was that climbing chimneys per se have never contributed to the disease because it did not appear in the boys who climbed the chimneys but only in adults when their climbing days were long behind them. The adult sweeps, however, had been in the habit of sifting the soot in order to remove debris from it before selling it. With the fall in the price of soot, the sweeps no longer bothered to sift it and hence were no longer subjected to the frictional trauma caused as the scrotum rubbed against soot-covered clothes during the sifting operations. This, said Lawson, was the most likely cause of the decline in the number of cases.

Butlin did not comment on the correctness of Lawson's hypothesis; he was far from convinced that there had been a real decline in the incidence of the disease. His experience at St Bartholomew's Hospital suggested that the incidence had remained at a constant, but low, rate at least during the 20 to 30 
years before the time he was writing. His theory was that the origin of the belief in the decline of the disease was to be found in a remark in Holme's System of Surgery published in 1864. In that book Humphrey had stated that the disease appeared to be on the decrease, perhaps owing to the more general use of machines. This opinion had appeared regularly thereafter in other surgical works until constant repitition had established it as an indisputable truth. Butlin was able to show that between 1869 and 188839 cases of scrotal cancer had been admitted to his hospital and that there was scarcely a year during which there was not at least one new case of the disease on the wards. ${ }^{24}$ Other London hospitals whose records Butlin examined (University College, the Middlesex, the Westminster, and St Thomas's) were also regularly admitting patients in small numbers. No less an authority than Dr William Ogle, the Registrar General, attempted to counter the prevailing view regarding the decline in chimney sweeps' cancer. In the 45th supplement to the annual report ${ }^{25}$ Ogle showed that of the 242 deaths which had occurred in sweeps in the years 1880-2, no less than 49 were attributable to cancer. Ogle calculated that sweeps were about eight times as likely to develop malignant disease as the general male population. He concluded that:

"These figures scarcely support the belief expressed by some authorities that improvement in the art of sweeping and habits of sweeps have caused this disease to be comparatively infrequent among them."

Be that as it may, fewer cases were reported in sweeps after the end of the 1870 s although the incidence of the disease remained higher in sweeps than in any other occupational group until the 1940 s even though their contribution to the total number of cases was surpassed by other workers. ${ }^{26}$

\section{Workers with the distillates of coal}

The first public notice that the distillation of coal might induce carcinoma of the scrotum was given by von Volkmann at the Third Surgical Congress in Berlin in 1873. Two years later the cases to which he had referred were published. ${ }^{27}$ They were:

\footnotetext{
"Three cases of . . . cancer of the scrotum which ... developed in workmen who were employed in brown-coal-tar and paraffin manufacture and ... even in the smallest details, both of their clinical course and anatomical structure ... agreed absolutely with the so-called chimney-sweeps' cancer of the English."
}

Tar from gas works, blast furnaces, and coke ovens was used widely from the end of the nineteenth century, both in the original state and for the distillation of a series of hydrocarbons including creosote, anthracene, and naphthalene. The residue remaining after distillation was pitch and, depending on whether or not all the anthracene was driven off, the pitch was hard or soft. What was loosely called paraffin was one of the distillates which became waxy on cooling and was used for candle making and so on. The paraffin workers in the early literature were the men who handled this solid wax. (The term paraffin worker was also applied to men handling a similar type of wax derived from shale oil and from petroleum oil.)

Volkmann's report was quickly followed by others, much as Pott's tract a century earlier had signalled the appearance of other cases of chimney sweeps' cancer. These later reports ${ }^{28-31}$ contained a further 25 accounts of the disease but when Kennaway examined them closely, he found that they related to only 10 patients. ${ }^{32}$ Eckhardt's thesis, ${ }^{30}$ for example, purported to describe four new cases, but these were found to be those which Schuchardt had described the previous year. ${ }^{29}$ The descriptions were so similar that, for the most part, they were identical.

Genuinely new cases, however, were not long forthcoming from Britain. ${ }^{22}{ }^{33-35}$ Pitch and tar were put to many uses. Henry, for example, in a list which was by no means exhaustive, mentioned 17 different occupations using one or the other, ${ }^{26}$ and this resulted in a much more universal distribution of the disease than had been the case for the chimney sweeps' cancer. Thus it occurred in America, ${ }^{36}{ }^{37}$ Canada ${ }^{38}$ France, ${ }^{39}$ Germany,${ }^{40}$ Holland, ${ }^{41}$ and Ireland. ${ }^{42}$ The manufacture of patent fuels from pitch, which had been established in South Wales in about 1859, appeared to constitute a particular hazard during the 1890 s and $1900 \mathrm{~s}^{43}$ The departmental committee which sat in 1907 to consider compensation for industrial injuries heard evidence on this point and came to the conclusion ${ }^{44}$ that:

"Men engaged in handling pitch, or other tarry pro-
ducts, either in unloading pitch from vessels or rail-
way trucks, or in the manufacture of briquettes, or in
handling "coal oil" in the manufacture of grease, are
liable to suffer from warty growths which ulcerate and
occasionally become the seat of epitheliomatous
cancer."

The committee recommended that men developing cancer as the result of their work in these occupations should receive compensation and as a consequence of their report in 1907 the definition "scrotal epithelioma occurring in chimney sweeps and epitheliomatous cancer or ulceration of the skin occurring in the handling or use of pitch, tar, and tarry compounds" was added to the third schedule of the Workmen's Compensation Act. 
It was a curious feature that neither blast furnace tar nor pitch appeared to be carcinogenic and neither was found experimentally to augment mitosis in leucocytes in the way which the carcinogenic gas works tar and pitch did. ${ }^{45}$ Leitch failed to produce cancer in mice when blast furnace tar was applied to the skin ${ }^{4647}$ and Legge stated that he had seen no cases of skin cancer among blast furnace workers. ${ }^{48}$ Later work by Berenblum ${ }^{49}$ and Bonser, ${ }^{50}$ however, showed that blast furnace tar was weakly carcinogenic to mice, but human cases were never notified. The reason seems to have been related to the different type of coal used (splint coal), the small amount of tar produced by the coal, and the small number of men who actually came into contact with it in the course of their work. ${ }^{26}$

The discovery of cancer in men handling tar and tar products excited a great deal of experimental work in an attempt to reproduce the effect in the laboratory. Hanau, using rats as his model, was probably the first to try, ${ }^{51}$ but he was unsuccessful as were the many others who followed him, ${ }^{52}$ and it was not until 1914 that Yamagiwa and Ichikawa were able to produce papillomas on the ears of rabbits by the repeated application of $\operatorname{tar}^{53}$ In the next year they reported the development of carcinomatous change but confirmation of their results had to wait until the end of the first world war when an intensive search was undertaken to identify the specific carcinogens in the various coal tar fractions. Kennaway was most prominent in this work, and he produced several important papers in the 1920s and 1930 s. $^{3254-58} \mathrm{He}$ was able to show that carcinogenicity was confined to those tars which were formed at high temperatures and that there was a relationship between the boiling point of the tar and pitch distillates and their carcinogenicity such that only those fractions with the higher boiling points were biologically active. Other studies showed that the fluorescence spectra of the carcinogens from tar were similar to that of 1,2 benzanthracene (benz(a)anthracene), although the absolute wave lengths were different. Kennaway was led by these findings to experiment with synthetic hydrocarbons. After a great deal of work he found that tumours in mouse skin could be produced by pure $1,2,5,6$ dibenzanthracene. $^{56}$ (This compound was incorrectly identified in the original paper as 1, 2, 7, 8 dibenzanthracene; the mistake was corrected in a later paper. ${ }^{59}$ ) Kennaway's work was later extended by Cook, who showed that several other chemicals containing the 1,2,5,6 dibenzanthracene ring system were also carcinogenic. ${ }^{60}$ Kennaway did not isolate a carcinogen from tar himself, but Cook and his colleagues isolated a highly carcinogenic crystalline compound from the distillate from two tons of pitch and showed this to be 3, 4 benzpyrene (benzo(a)pyrene). ${ }^{\circ}$

\section{Mineral oil workers}

SHALE OIL WORKERS

Shale oil is a mineral oil extracted from shale by destructive distillation. It was first used to produce naptha (used as a motor fuel and as a solvent), lubricating oil, and solid paraffin from which the oil had been expressed mechanically and which was used for making candles.

The shale oil industry was established on a large scale in the early 1850 s by James Young utilising the shale deposits in Scotland. The oil which was produced supplemented and finally replaced the fish and animal oils then used for lubricating machinery and it was of particular importance to the Lancashire cotton industry. After the discovery of petroleum oil, shale oil became increasingly uneconomic and by 1872 it had been replaced in the cotton mills by lubricants derived from petroleum ${ }^{62}$; it was produced in Scotland until 1962 with the help of government subsidies, however.

Cases of scrotal cancer in shale oil workers were presented to the Medico-Chirurgical Society of Edinburgh by Joseph Bell in $1876 .^{63}$ Bell commented that if chimney sweeps' cancer was becoming rare, then:

"I believe we are to find a successor for it in a malady. affecting the labourers exposed to the fumes of paraffin in shale works."

Bell was not, in fact, the first to see scrotal cancer in a shale oil worker. Kirk had seen a case in 1875 , but delayed publication until 1903.64 There is some evidence that cases occurred even before this. A report in the Glasgow Medical Journal in 1879, commenting on a case of Cameron's, noted that physicians who had direct dealings with the paraffin workers had long been familiar with the disease. ${ }^{65}$

It was almost 20 years before the next case was reported $^{66}$ and scrotal cancer was never common among the shale workers. Scott, for example, was able to find only 31 cases between 1900 and 1921. ${ }^{6768}$ Although Leitch was able to show the carcinogenicity of shale oil in the laboratory, ${ }^{69}$ it was soon seen to be a less serious hazard than other kinds of mineral oil to which men were exposed.

\section{MULE SPINNERS}

Cases of scrotal cancer among the mule spinners of Lancashire came to the attention of the factory department of the Home Office from 1876 onwards, ${ }^{70}$ although the first death ascribed to the disease was not apparently registered until $1887 .{ }^{26}$ 
The first published account of the frequency with which the disease occurred in the north west was given by Morley in 1911 in a paper concerned chiefly with the anatomy of the lymphatic drainage of the scrotum. ${ }^{71}$ Morley's work was prompted in part by the investigations of SR Wilson which were contained in his prize essay written for the Tom Jones Surgical Research Scholarship at the University of Manchester and submitted in $1910 . .^{72}$ Wilson was able to collect together 40 cases of scrotal cancer and noted that:

"in no single instance did the patient follow the occupation of chimney sweep. On the other hand over $80 \%$... are spinners most of them belonging to the class of mule spinners."

Wilson was not clear how the disease was caused but he thought that it might be related to friction between the scrotum and the overalls the men wore, the slight trauma produced being aggravated by the presence of sweat and dust. As an alternative, he suggested that the grease which got on to the men's clothing might be radioactive. He did not consider exposure to oil to be a factor, and it was only much later, when a revised version of the essay was published with Southam that mineral oil was mentioned in this context. ${ }^{72}$

Wilson's original essay was never published in its entirety, and indeed he did not retain much interest in the subject, but specialised in anaesthetics, meeting his death from self experimentation with nitrous oxide in $1927 . .^{73}$ In the year after his death Brockbank and Stopford published annotated extracts from the essay, the manuscript of which is still in the possession of the University of Manchester. ${ }^{74}$

In the 1920s the disease assumed almost epidemic proportions in the cotton industry. Mineral oil was by this time well recognised as being carcinogenic and, in 1914, "Bitumen, mineral oil or paraffin or any compounds or products or residue of any of these substances" had been added to the schedule of the Workmen's Compensation Act. In 1920 notification to the Factory Inspectorate of epitheliomatous ulceration caused by the substances in the schedule and the full extent of the disease became apparent. The increase in the number of notifications in mineral oil workers (fig 6) led the Home Office, in 1925, to appoint a committee to "Consider evidence as to the occurrence of epitheliomatous ulceration among mule spinners." The secretary of the committee was SA Henry, the third of the important writers on scrotal cancer. Henry (1880-1960) began his professional life as an assistant school medical officer in Wales. He then entered general practice in Rochdale where he was appointed as a certifying surgeon under the Fac-

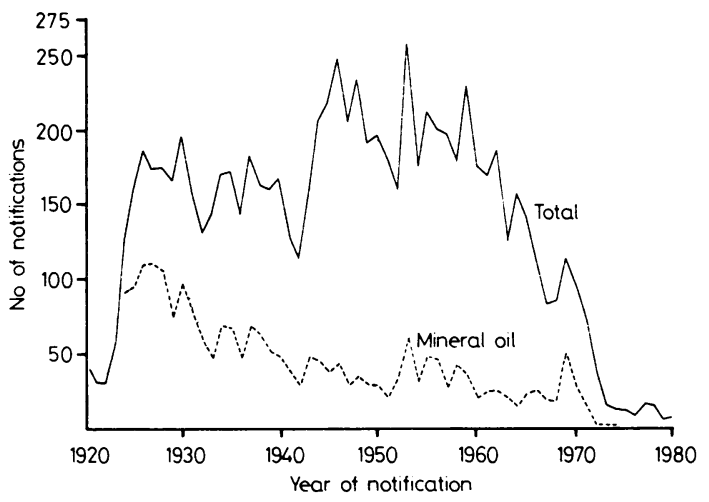

Fig 6 Number of notifications of epitheliomatous ulceration, 1920-80. Total number of cases shown by solid line, those caused by exposure to mineral oil shown by broken line.

tories and Workshops Act. In this capacity he met Sir Thomas Legge with whom he developed a close friendship. In 1920, no doubt at Legge's instigation, he was appointed as the fourth Medical Inspector of Factories and became especially interested in occupational cancer. His monograph on Cancer of the Scrotum in Relation to Occupation published in $1946^{26}$ is the work by which he will be best remembered.

Henry's committee reported with commendable speed in 1926 . They came to the conclusion that the mineral oil thrown off the spindle of the mule by the centrifugal force generated during working was responsible for causing the disease. They recommended that research should be instigated to find new lubricants which were not carcinogenic, that non-splash spindle bearing should be developed, and that anti-splash guards should be fitted to the mules. It was also recommended that each worker over the age of 30 employed in the spinning room should have a medical examination every four months. The committee suggested that the medical inspections should be voluntary on the part of the worker, but that if the response were poor then they should become compulsory.

Several writers commented on the prediliction for the scrotum as the site of the disease among the mule spinners, and it was eventually explained by the presence of the faller bar in front of the machine. The spinner's job was to piece up ends of the yarn which broke as it was being spun. In doing so, he leaned across the faller bar (fig 7) which was at groin height and was thus brought into contact with oil on the bar. ${ }^{75}$ The temperature in the mills was high and the spinners wore a minimum of clothing; a shirt and a pair of linen trousers were usually enough and the 


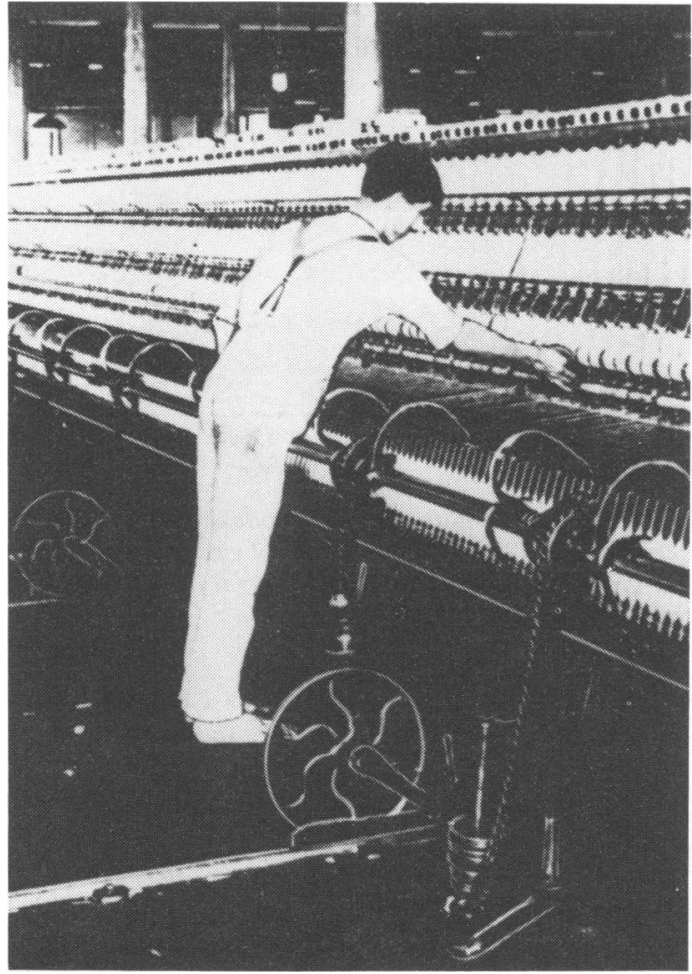

Fig 7 A cotton mule spinner at work in 1930s. Note how he leans across faller bar to mend a broken thread.

feet were bare. Southam and Wilson noted that the trousers of the spinners showed:

"a well marked oil zone, six to eight inches in depth, across the body at the level of the upper part of the thighs and lower abdomen. This oil penetrates the trousers and the lower border of the shirt also becomes soaked with it." 72

The case against mineral oil seemed conclusive, the more so as Leitch had already shown it to be carcinogenic to mice. ${ }^{76}$ An opposite point of view, however, was taken by Robertson, the Medical Officer of Health for Darwen. He contended that the oil was not thrown off on to the faller bars which, he maintained, were free from oil; in some mills he even found them to be rusty. ${ }^{77}{ }^{78}$ Robertson concluded that oil found on the overalls of the cotton workers was picked up from the floor of the mill, spreading up the trouser leg by capillary action, but never high enough to come into contact with the groin. Thus it could not be implicated in the aetiology of the disease which he considered to be due to the friction between the rough overalls and the scrotum, with the blue aniline dye in the material acting as angravating factor.
Robertson considered his theory to be supported by the absence of scrotal cancer among wool spinners who wore soft underpants beneath their overalls, thus avoiding frictional trauma. This observation has also been made by others ${ }^{79}$ and the difference between the cotton and wool mule: spinners with respect to the prevalence of scrotal. cancer has never been satisfactorily explained. Several factors have been suggested, however, including differences in the processes and the presence of animal oils in the wool which might, in some way, protect against the disease. ${ }^{80}$

Robertson's frictional theory was later revived by Somerford ${ }^{81}$ but was countered by Irvine ${ }^{82}$ This debate took place in 1935 , by which time the experimental evidence to support the carcinogenic role of mineral oil was sufficient to make further discussion fruitless and Robertson's theory, like George Lawson's before it, was no longer given credence.

Much of the experimental work on the carcinogenic effects on mineral oil was carried out in Manchester under the auspices of the Manchester Committee on Cancer, which was formed in 1925 under the direction of CC Twort. A series of papers was published by Twort and his colleagues ${ }^{83-90}$ in which it was shown that many of the spindle oils, and other oils, used in the cotton industry were carcinogenic to mice in varying degrees. Lighter spindle oil has a higher potency than the heavy oils used for lubricating machinery or as transformer or motor oils; highly refined oils were less active than crude oils. Twort and his colleagues were also able to show that oils of low potency became more active with long use due to the formation of new compounds by cracking. The higher the temperature of cracking, the more carcinogenic the oil became. They also showed that the carcinogenic activity of oils could be diminished by treatment with sulphuric acid.

A practical result of Twort's work was that in 1945 an agreement was reached between the employers, the trade unions, and the Factory Department that only refined spindle oils with particular physical properties would be used in the cotton industry. These oils came to be known as Twort or $\mathrm{NC}$ (non-carcinogenic) oils.

Several disadvantages in this system of classifying NC oils soon became apparent, however, the most serious being that oils which conformed to the standard were not invariably inactive and that it was possible to mix two oils, neither of which conformed to the specification, in order to produce one that did. Woodhouse and his colleagues showed that some grades of white oil were inactive in mice and later experiments showed them to be also inactive in rabbits. ${ }^{91}$ As soon as the petroleum industry was able to 
produce inert white oils of an acceptable lubricating efficiency, it became obligatory to use them in the cotton industry under the terms of the Mule Spinners (Health) Special Regulations of 1954.

\section{ENGINEERING WORKERS}

The incidence of scrotal cancer in Lancashire has fallen since the 1920 s due not only to improved hygiene in the industry but also as a reflection of the general decline in the cotton industry. ${ }^{92}$ Scrotal cancer, however, has made its appearance in other classes of workmen exposed to mineral oil. These include men in the jute industry, ${ }^{93}$ those handling paraffin wax, ${ }^{9495}$ and, especially, those men in the engineering industry who have been exposed to cutting oils.

Cutting oils are used in the engineering industry to lubricate and cool the interface between a cutting tool and the metal being worked. They may be used neat or as water based emulsions (so called soluble or suds oils) and, in addition, some synthetic cutting fluids are available. A number of additives may be incorporated into the oils including antioxidants, antirust, and antiwear agents, extreme pressure agents, detergents, and antimicrobials. The composition of many of the additives is kept secret, but among those that have been used are mercury and lead naphthenate. Lead naphthenate is readily absorbed through the skin, and cases of lead poisoning have resulted from its use..$^{96}$ It has also been suggested (although probably incorrectly) that the carcinogenicity of some oils may be partly due to their content of lead naphthenate. ${ }^{97}$

The first indication that exposure to cutting oils might produce scrotal cancer appeared in 1950 in a paper by Cruickshank and Squire..$^{98}$ These authors analysed the occupations of men treated for scrotal cancer in the United Birmingham Hospitals during a 10 year period. Thirty four patients were traced of whom 12 had been exposed to mineral oil, six during the course of their work as machine tool operators. In the same paper they were also able to show experimentally that cutting oils were carcinogenic to laboratory animals, work that was subsequently confirmed by Gilman and Vessolinovitch. ${ }^{99}$ Bearing in mind that the introduction of automatic machines on a large scale, and hence the use of cutting oils, was relatively recent, and that the latent period of the disease was long Cruickshank and Squire predicted that the incidence of scrotal cancer would rise in the decade following their investigation. ${ }^{98}$ This has proved to be the case in the West Midlands ${ }^{100}$ and, in addition, cases have also been described in other areas of the United Kingdom ${ }^{101}$ and in many other countries including the United States, ${ }^{102}$ Canada, ${ }^{103}$ France, ${ }^{104}$ (particularly in the Arve val-

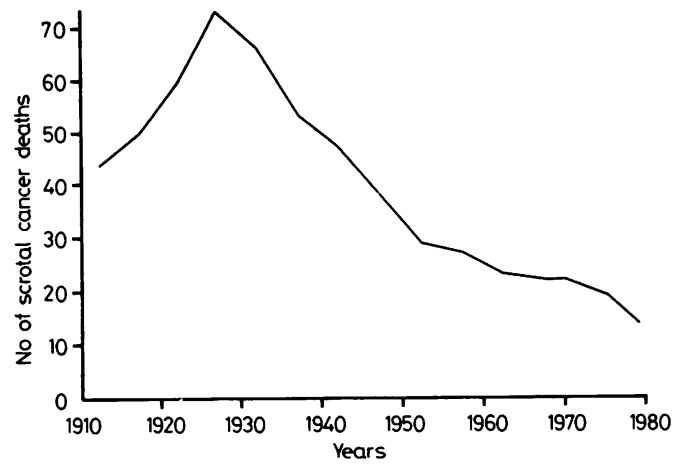

Fig 8 Number of deaths from scrotal cancer, 1910-80. Reproduced with the kind permission of Dr MR Alderson.

ley), ${ }^{105}$ Norway, ${ }^{106}$ and Sweden. ${ }^{107}$ In Holland cases do not occur among workers exposed to mineral oil $^{108}$ and for many years the disease was unknown in Australia, ${ }^{109}$ although cases have now been registered in Victoria. ${ }^{110}$

There was a considerable increase in interest in the connection between exposure to cutting oils and scrotal cancer after the action for compensation brought against an engineering firm by the widow of a man who died from the disease (Strokes $v$ GKN Nuts and Bolts Ltd, 1968). Noting the publicity given to the case, the Senior Medical Inspector of Factories predicted that the number of notified cases would increase, suggesting that it had previously been underreported because doctors were not aware that the disease might have an occupational origin. ${ }^{111}$ His prediction was fulfilled when the following year the number of notifications of scrotal cancer rose from 19 to 43 and the total number of cases of epitheliomatous ulceration increased from 83 to 111 . The number of notifications from the West Midlands Region rose from four in 1968 to 17 in $1969 .^{112}$ Since 1969 , however, the number of notified cases of epitheliomatous ulceration has declined and the number of deaths from the disease is now also low (fig 8).

\section{References}

' Pott P. Chirurgical observations. Vol 3. London: L Hawes, W Clark, and R Collins, 1775:177-83.

${ }^{2}$ Kipling MD, Usherwood R, Varley R. A monstrous growth: an historical note on carcinoma of the scrotum. $\mathrm{Br} J$ Ind Med 1970;27:382-4.

${ }^{3}$ Anon. Chimney sweeping described, with a view to the emancipation of climbing boys. London: no publisher, undated.

4 Children's Employment Commission. First report. London: HMSO, 1865.

${ }^{5}$ Kipling MD, Waldron HA. Percivall Pott and cancer scroti. Br J Ind Med 1975;32:244-6. 
- Earle H. On chimney-sweeper's cancer. Medical and Surgical Journal 1832;1:6-8.

7 Green RM. Cancer of the scrotum. Boston Medical and Surgical Journal 1910;163:755-9, 792-7.

${ }^{8}$ Earle J. Annotation. In: Pott's works. Vol 3. London: LH Harres, W Clarke, R Collins, 1790:257-8.

${ }^{9}$ Curling TB. A practical treatise on diseases of the testis and of the spermatic cord. London: Longman, Green, 1866.

${ }^{10}$ Paget J. Lectures on surgical pathology. Vol 2. London: Longman, Brown, Green, and Longman, 1853:464.

" Dixon. Chimney sweeper's cancer. Lancer 1850;i:337-8.

12 Lawson G. Chimney-sweeps' cancer. Br Med J 1868;i:351

${ }_{13}$ Jeffreys. A case of malignant ulceration of the scrotum commonly called chimney sweepers' cancer. Lnacet 1825;8:318-9.

${ }^{14}$ Cooper A. Observations on the structure and diseases of the testis. London: Longman, Rees, Orme, Brown, and Green, 1830:226.

is Hutchinson J. On some examples of arsenic-keratosis of the skin and arsenic cancer. Transactions of the Pathological Society of London 1888;39:356-61.

${ }^{10}$ Wright R. In: Report from the committee on the employment of boys in sweeping chimneys. London: HMSO, 1817:24.

17 Bird PH. Cancer of the scrotum. Provincial Medical and Surgical Journal 1849;15:127-9.

${ }^{18}$ Travers $\mathrm{R}$. On the local diseases termed malignant. MedicoChirurgical Transactions 1832;17:344-6.

19 Cooper B. Chimney sweepers' cancer. London Medical Gazette 1849;43:530-3

${ }^{20}$ Spencer WG. Soot in cells of chimney-sweepers' cancer. Medico-Chirurgical Transactions 1890-1;74:59-75.

21 Passey RD. Experimental soot cancer. Br Med J 1922;ii:11123.

${ }^{22}$ Butlin HT. Cancer of the scrotum in chimney sweeps and others. Br Med J 1892;i:1341-6, 1892;ii:1-6, 66-71.

${ }^{23}$ Lawson G. On the probable cause of the diminution of chimney-sweeps' cancer. $\mathrm{Br}$ Med J 1878;ii:576-7.

${ }^{24}$ Butlin HT. On the operative surgery of malignant disease of the scrotum. St Batholomew's Hospital Reports 1889;25:193-200.

${ }^{25}$ Ogle W. In: Supplement to 45th annual report of the registrar general. London: HMSO, 1885;56.

${ }^{26}$ Henry SA. Cancer of the scrotum in relation to occupation. London: Oxford University Press, 1946.

${ }^{27}$ von Volkmann R. Beitrage sur Chirurgie. Leipzig: Breitkopf und Hartel, 1875:370.

28 Tillmans H. Uber Theer-, Russ- und Tabak-Krebs. Deutsche Zeitschrift für Chirurg 1880;13:519-28.

${ }^{29}$ Schuchardt K. Beitrage zur Entstehung der Carcinoma aus chronische entzundlichen Zustanden der Schleimhaute und Hautdecker. Sammlung Klinische Vorträge (Leipzig) 1885; 257:2195-99.

${ }^{30}$ Eckhardt P. Vier neue Falle von Paraffinkrebs. Halle: 1886 (Thesis.)

${ }^{31}$ Leibe G. Ueber der Teer- oder Paraffinkrebs. Schmidt's Jahrbuch 1892:236:71-80.

${ }^{32}$ Kennaway EL. On cancer-producing tars and tar fractions. $J$ Ind Hyg 1924;5:462-88.

${ }^{33}$ Power D. A case of epithelioma of the scrotum occurring in a tar worker. Transactions of the Pathological Society of London 1893-4;45:21!-6.

${ }^{34}$ Oliver T. Tar and asphalt workers' epithelioma and chimneysweeps' cancer. Br Med J 1908;ii:493-4.

${ }^{35}$ Ross HC. Occupational cancer. J Cancer Res 1918;3:321-56.

${ }^{36}$ Schamberg JF. Cancer in tar workers. Journal of Cutaneous Disease 1910;28:644-62.

${ }^{37}$ Davis BF. Paraffinoma and wax cancer. JAMA 1920;75:170912.

${ }^{38}$ Hutchinson JA. Epithelioma of the scrotum. Montreal Med J 1906;35:376-9.

${ }^{39}$ Courmont P. Tar cancer in France. Journal of State Medicine $1924 ; 32: 539-41$.
${ }^{40}$ Teutschlaender A. Occupational cancer in two briquette factories in Baden (Germany). In: Report of the international congress on cancer. Bristol: John Wright and Sons, 1928:289.

${ }^{41}$ de Vries WM. Pitch cancer in the Netherlands. In: Report of the international congress on cancer. Bristol: John Wright and Sons, 1928:290-2.

${ }^{42}$ Ball CB. Tar cancer. Transactions of the Academy of Medicine of Ireland 1885;3:318-20.

${ }^{43}$ Downing CCR. Cutaneous papillomas among patent fuel workers in relation to malignant disease. $J$ Ind Hyg 1932;14:25579.

${ }^{44}$ Departmental committee on compensation for industrial diseases. Report. London: HMSO, 1907.

${ }^{45}$ Ross HC, Cropper JW. The gas-works pitch industries and cancer. Br Med J 1911;i:884-6.

${ }^{46}$ Leitch A, Kennaway EL. Experimental production of cancer by arsenic. $\mathrm{Br}$ Med J 1922;ii:1107-9.

${ }^{47}$ Leitch $\mathrm{A}$. The experimental inquiry into the causes of cancer. $\mathrm{Br}$ Med J 1922;ii: 1-5.

${ }^{48}$ Legge TM. Epitheliomatous ulceration in industry. $\mathrm{Br} \mathrm{Med} \mathrm{J}$ 1922;ii:1110-1.

${ }^{49}$ Berenblum I. Experimental induction of tumours with blast furnace tar. Lancet 1930;ii:1344-7.

${ }^{\text {so }}$ Bonser GM. Tumours of the skin produced by blast furnace tar Lancet 1932;i:775-8.

si Hanau A. Erfolgreiche experimentelle Ubertragung von Carcinom. Fortshor Med 1889;7:321-30.

52 Woglom WH. Experimental tar cancer. Arch Pathol Lab Med 1926;2:533-8.

${ }^{53}$ Yamagiwa K, Ichikawa $K$. Experimental study of the pathogenesis of carcinoma.J Cancer Res 1918;3:1-29.

${ }^{54}$ Kennaway EL. On the cancer-producing factor in tar. $\mathrm{Br} \mathrm{Med} J$ 1924;i:564-7.

ss Kennaway EL. The formation of a cancer-producing substance from isoprene (2-methyl butadiene). Journal of Pathology and Bacteriology 1924;27:233-8.

${ }^{56}$ Kennaway EL. Experiments on cancer-producing substances. Br Med J 1925;ii: 1-4.

57 Kennaway EL. Further experiments on cancer-producing substances. Biochem J 1930;24:497-504.

${ }^{58}$ Kennaway EL, Hieger I. Carcinogenic substances and their flourescence spectra. Br Med J 1930;i:1044-6.

${ }^{59}$ Cook JW, Heiger I, Kennaway EL, Mayneord WV. The production of cancer by pure hydrocarbons. Proc $R$ Soc Lond $B$ 1932;111:455-84.

${ }^{60}$ Cook JW. The production of cancer by pure hydrocarbons. Proc $R$ Soc Lond 1932:111:485-93.

${ }^{\circ}$ Cook JW, Hewett CL, Hieger I. Coal tar constituents and cancer. Nature 1932;130:926-8.

${ }^{62}$ Legge TM. In: Report of chief inspector of factories for 1923. London: HMSO, 1924:71

${ }^{63}$ Bell J. Paraffin epithelioma of the scrotum. Edinburgh Medical Journal 1876-7;22:135-7.

64 Kirk R. Paraffin cancer. Br Med J 1930;ii:1528-30.

os Cameron A. Epithelioma of scrotum in a paraffin worker ("paraffin cancer"). Glasgow Medical Journal 1879;12:40-2.

${ }^{60}$ Buchanan G. Specimen of "paraffin" epithelioma. Transactions of the Glasgow Pathological and Clinical Society 1893 4;5:165-7.

${ }^{67}$ Scott A. On the occupational cancer of the paraffin and oil workers of the Scottish shale oil industry. $\mathrm{Br}$ Med $\mathrm{J}$ 1922;ii: $1108-9$.

${ }^{\circ 8}$ Scott A. Cancers in mineral oil refineries. In: Report of the international congress on cancer. Bristol: John Wright and Sons, 1928:275.

${ }^{69}$ Leitch A. Paraffin cancer and its experimental production. $\mathrm{Br}$ Med J 1922;ii:1104-6.

${ }^{70}$ Legge TM. In: Annual report of HM chief inspector of factories for the year 1925. London: HMSO, 1926:63.

"Morley J. The lymphatics of the scrotum in relation to the radi- 
cal operation for scrotal epithelioma. Lancet 1911 ;ii:1545-7.

${ }^{72}$ Southam AH, Wilson SR. Cancer of the scrotum: the aetiology. clinical features, and treatment of the disease. $\mathrm{Br} \mathrm{Med} \mathrm{J}$ 1922;ii:971-3.

${ }^{3}$ Anon. Obituary SR Wilson. Br Med J 1927;ii:570-1.

${ }^{4}$ Brockbank EM. Stopford JSB. Scrotal cancer in cotton mulespinners. Br Med J 1927:ii:993-5.

"Brockbank EM. Mule spinners cancer. Epithelioma of the skin in cotton spinners. London: HK Lewis and Co, 1941.

${ }^{76}$ Leitch A. Mule-spinners' cancer and mineral oils. Br Med J 1924,iii,941-3.

"Robertson J. Mule-spinners' cancer. Br Med J 1926;ii:1181-2.

${ }^{\prime}$ Robertson J. An inquiry in regard to the cause of spinners' scrotal cancer. Journal of Industrial Hygiene 1927:9:217-38.

${ }^{74}$ Brockbank EM. Mule spinners cancer. Br Med J 1926;ii:11823.

${ }^{\text {xo }}$ Lee WR, McCann JK. Mule spinners' cancer and the wool industry. Br J Ind Med 1967;24:148-52.

"Somerford AR. Aetiology of cancer of the skin with special reference to occupation. $\mathrm{Br}$ Med J 1935;i: 1305-10.

${ }^{* 2}$ Irvine ED. A note on cutaneous cancer in cotton mule-spinners. Br Med J 1935;ii:996-7.

${ }^{* 3}$ Twort CC. Ing HR. Mule-spinners cancer and mineral oils. Lancet 1928;i:752-4.

${ }^{\times 4}$ Twort CC, Fulton JD. Experiments on the nature of the carcinogenic agents in mineral oils. J Pathol 1929;32:149-61.

${ }^{*}$ Twort CC. Lyth R. The selection of non-carcinogenic from carcinogenic oils. J Hyg 1933;33:464-73.

${ }^{86}$ Twort CC. Lyth R, Twort JM. The significance of density, refractive index and viscosity of mineral oils in relation to the type and degree of animal reaction. $J$ Hyg 1937;37:14-29.

${ }^{87}$ Twort CC. Twort JM. The relative potency of carcinogenic tars and oils. J Hyg 1930;30:373-9.

${ }^{8 *}$ Twort CC, Twort JM. The carcinogenic properties of mineral oils. J Hyg 1931;31:204-26.

${ }^{k 4}$ Twort CC, Twort JM. Suggested methods for the standardisation of the carcinogenic activity of different agents on the skin of mice. Am J Cancer 1935:17:293-320.

*) Twort CC. Twort JM. Induction of cancer by cracked mineral oils. Lancet 1935;ii: 1226-8.

"Hieger I, Woodhouse DL. The value of the rabbit for carcinogenicity tests on petroleum fractions. $\mathrm{Br} J$ Cancer 1952:1:293-9.

${ }^{92}$ Lee WR, Alderson MR, Downes JE. Scrotal cancer in the north-west of England. Br J Ind Med 1972;29:188-95.

${ }^{93}$ Roe FJC, Carter RI, Taylor W. Cancer hazard from mineral oil used in the processing of jute. Br J Cancer 1967;21:694-702.

${ }^{94}$ Dean AL. Epithelioma of scrotum. J Urol 1948;61:508-18.

${ }^{95}$ Lione JG, Denholm JS. Cancer of the scrotum in wax pressmen. II Clinical observations. Archives of Industrial Health 1959;19:530-9.

${ }^{90}$ Kipling MD. Oil and the skin. Transactions of the Association of Industrial Medicine Officers 1963;13:22-4.

${ }^{97}$ Baldwin RW, Cunningham GJ, Pratt B. Studies on the carcinogenic action of motor engine oil additives. $\mathrm{Br} \mathrm{J}$ Cancer 1961;15:123-8.

${ }^{98}$ Cruickshank CND, Squire JR. Skin cancer in the engineering industry from the use of mineral oil. Br J Ind Med 1950;7:111 .

${ }^{* 9}$ Gilman JPW, Vessolinovitch SD. Cutting oils and squamous cell carcinoma. Br J Ind Med 1955;12:244-8.

100 Waldron HA, Waterhouse JAH. Tessema N. Scrotal cancer in the West Midlands. Br J Ind Med (in press).

101 Fife JG. Carcinoma of the skin in machine tool setters. Br J Ind Med 1962;19:123-5.

${ }^{102}$ Kickman CJE, Dufresne M. An assessment of carcinoma of the scrotum. J Urol 1967;98:108-13.

${ }^{103}$ Mastromatteo E. Cutting oils and squamous cell carcinoma. Br J Ind Med 1955;12:240-3.

104 Carteud A. Cancer du scrotum du au goudron on a ses derives. La Presse Medicale 1964;72:3355-60.

${ }^{105}$ Kipling MD. Oil cancer in the Savoy alps and the Birmingham region: a comparison. Transactions of the Society of Occupational Medicine 1971;21:73-8.

106 Wannig A. Kreftrisiko og oljeeksposisjon. Tidsskrift for den Norske Laegeforening (Oslo) 1972;92:1136-40.

${ }^{107}$ Avellan L, Breine U, Jacobsson B, Johanson B. Carcinoma of scrotum induced by mineral oil. Scand J Plast Reconstr Surg 1967:1:135-40.

${ }^{108}$ Pruym FHAM, Reijnierse K. Scrotum-carcinoon door minerale oilein. Tijdschrift voor Sociale Geneeskunde 1972;50:182-7.

${ }^{109}$ Longley EO. Scrotal carcinoma. Br Med J 1969;i:777.

${ }^{10}$ Kipling MD. Oil and cancer. Ann $R$ Coll Surg Eng 1974:55:71-9.

"' Lloyd-Davies TA. In: Annual report of HM chief inspector of factories for 1968. London: HMSO, 1969:58-62.

112 Lloyd-Davies TA. In: Annual report of HM chief inspector of factories for 1969. London: HMSO, 1970:67-72. 